B I O S C I E N C E

J O U R N A

\section{METAL ACCUMULATION, GROWTH AND NUTRITION OF Vernonia polyanthes EXPOSED TO LEAD NITRATE AND ARBUSCULAR MYCORRHIZAL FUNGI}

Joacir MORAIS ${ }^{1}$ (D) Cácio Luiz BOECHAT² iD, Daniela Fernandes de OLIVEIRA ${ }^{3}$ iD, Adriana Miranda de Santana ARAUCO ${ }^{2}$ iD, Filipe Selau CARLOS ${ }^{4}$, Poliana Prates de Souza SOARES ${ }^{5}$

1 Postgraduate Program in Agricultural Science, Federal University of Piauí, Bom Jesus, Piauí, Brazil.
2 Campus Profa Cinobelina Elvas, Federal University of Piauí, Bom Jesus, Piauí, Brazil.
${ }^{3}$ Postgraduate Program in Soil Science, Federal University of Rio Grande do Sul, Porto Alegre, Rio Grande do Sul, Brazil.
${ }^{4}$ Campus Campus Capão do Leão, Federal University of Pelotas, Capão do Leão, Rio Grande do Sul, Brazil.
${ }^{5}$ Postgraduate Program in Agricultural Science, State University of Sudoeste da Bahia, Vitória da Conquista, Bahia, Brazil.

Corresponding author:

Joacir Morais

Email: moraisjoacir@gmail.com

How to cite: MORAIS, J., et al. Metal accumulation, growth and nutrition of Vernonia polyanthes exposed to lead nitrate and arbuscular mycorrhizal fungi. Bioscience Journal. 2021, 37, e37045. https://doi.org/10.14393/BJ-v37n0a2021-53697

\title{
Abstract
}

The association between plants and arbuscular mycorrhizal fungi (AMF) can be used to bioremediate areas contaminated by metals. The objectives of this work were to evaluate the lead $\left(\mathrm{Pb}^{2+}\right)$ phytoaccumulation capacity, morpho-physiology and nutrition responses of Vernonia polyanthes exposed to a solution amended with concentrations of lead nitrate and arbuscular mycorrhizal fungi. The treatments consisted of increasing doses of $\mathrm{Pb}^{2+}$ as lead nitrate $\left[\mathrm{Pb}\left(\mathrm{NO}_{3}\right)_{2}\right]$, two strains of $\mathrm{AMF}$ and an absolute control without lead and AMF. Lead negatively affected some morphophysiological variables, reduced $27.3,25.63,30.60$, and 56.60\% shoot length, root collar diameter, number of leaves and leaf area, respectively, besides reducing decreasing chlorophyll $a$. Lead accumulated in the shoot and roots, the latter at the highest concentrations. However, the translocation factor was above 1, indicating low efficiency. The bioaccumulation factor referring to the roots were above 1 . The fungi colonization rate was low, 3.31\% for Gigaspora margarita and $2.33 \%$ for Acaulospora morrowiae. However, the absorption of lead increased, reflecting in lower values of chlorophyll $a$, dry mass of root and diameter. Results indicated that the arboreal species $V$. polyanthes tolerate high concentrations of lead and can accumulate significant amounts in the roots. AMF increase the accumulation of lead in the shoot and can be used in projects aimed at the phytoextraction of metals.

Keywords: Bioaccumulation Factor. Phytoextraction. Phytostabilization. Potential Toxic Element. Translocation Factor.

\section{Introduction}

The lead is naturally found in rocks and the main lead mineral is galena ( $\mathrm{PbS})$, but anglesite ( $\left.\mathrm{PbSO}_{4}\right)$ and cerussite $\left(\mathrm{PbCO}_{3}\right)$ are also common minerals. However, it has become a serious environmental problem due to the contamination of soils and water worldwide because of anthropogenic activities, and it is currently considered one of the greatest pollutants of terrestrial and aquatic ecosystems (Kabata-Pendias 2011; Yongpisanphop et al. 2017). About 78\% of the world production of $\mathrm{Pb}$ is used mainly to manufacture automotive batteries (Arias et al. 2015) and for other industrial processes, such as mining, foundry and galvanoplasty (Yang et al. 2015). The use of techniques that allow the removal of these contaminants, by environmental services at low cost and high capacity are acceptable to society and to the environmental authorities. Thus, bioremediation is underscored as an excellent option, since it refers to the use of plants 
and rhizospheric microorganisms to minimize the toxic effects of potential contaminants in the environment. This technology is based on the association between plants and soil microbes to reduce concentrations or toxic effects of contaminants in the environments and known as economically feasible and very efficient (Kabata-Pendias 2011; Boechat et al. 2016a; Ma et al. 2019).

Many plants establish a symbiosis with the arbuscular mycorrhizal fungi (AMF) as an evolutionary mechanism to render their development feasible at sites that are severely polluted by heavy metals. These can help the phytoremediation of the contaminated areas, making the metals more available for absorption by the plants or reducing the metal toxicity in the host plants (Arias et al. 2015; Coninx et al. 2017; Ma et al. 2019).

The effect of AMF improving the absorption of nutrients that are essential for the plants is widely known (Smith and Smith 2012; Vergara et al. 2019). However, information is scarce regarding the absorption and accumulation of metals including $\mathrm{Pb}^{2+}$ in the species Vernonia polyanthes (Asteraceae), and the influence of this metal on biomass production and suitability in phytoremediation projects. Vernonia polyanthes (Asteraceae) is a native species of Brazil, known popularly as assa-peixe, adapted to adverse conditions, such as soils with low fertility, acid and with a high concentration of phytotoxic aluminum $\left(\mathrm{Al}^{3+}\right)$. It is frequently found at garbage dumps and close to highways. According to Lajayer et al. (2017) it is essential to identify native plant species adapted to the region for the phytoremediation of metal-contaminated soils.

Vernonia polyanthes plants that are grown in an environment where urban garbage is discarded accumulate chrome in the shoot even if the metal ions are at a low concentration in the soil (Pereira et al. 2013). It is believed that $V$. polyanthes inoculated with arbuscular mycorrhizal fungi can absorb and translocate a large amount of lead. However, research on plants with a potential for phytoremediation is scarce in tropical areas, particularly in the Brazilian Northeast Cerrado biomes.

Considering this scenario, we choose to assess whether the species Vernonia polyanthes can be used in lead phytoremediation and/or phytostabilization projects. Thus, the objective of this study is to evaluate the phytoextraction and phytoaccumulation potential of lead $\left(\mathrm{Pb}^{2+}\right)$ by the arboreal species in symbiosis with strains of arbuscular mycorrhizal fungi.

\section{Material and Methods}

\section{Study site}

The experiment was conducted in a greenhouse at $70 \%$ light with an impermeabilized floor, located at the geographic coordinates 09. 04' 28" S and 44 21' 31" O, in the Northeast region of Brazil. The region climate is hot and humid and according to the Köppen classification it is of the Aw type, with mean precipitation between 900 - and $1200-\mathrm{mm}_{\text {year }}{ }^{-1}$ distributed during the period of October to April. During the experimental period humidity reached a mean of $78 \%$ and the temperature ranged between the minimum of $21 \stackrel{\circ}{\circ} \mathrm{C}$ and the maximum of $34 \stackrel{\circ}{\circ} \mathrm{C}$ with a mean of $25.93^{\circ} \mathrm{C}$ (INMET 2019).

\section{Preparation of seedlings and inoculation with AMFs}

Vernonia polyanthes seedlings were produced from approximately $15 \mathrm{~cm}$ high stakes inserted into plastic tubes with a capacity for $230 \mathrm{~cm}^{3}$, containing washed and autoclaved sand. The period of stake acclimation was approximately two months, and the plants were irrigated three times a day via an automated irrigation system.

After the acclimation period, the seedlings were transplanted to black plastic pots with a $3 \mathrm{~L}$ capacity, containing $1.5 \mathrm{~kg}$ of rough, washed and autoclaved sand, and filled up with $2.6 \mathrm{~L}$ of Hoagland and Arnon (1950) nutrient solution at $50 \%$ strength, without the heavy metals. Before transplanting the seedlings were standardized by the height of the shoot and then the roots were washed in tap water to remove the remainder of the sand that might potentially interfere in the experiment. The experiment followed a design in randomized blocks, with a factorial scheme of $4 \times 3$, with four concentrations of $\mathrm{Pb}(0,72,180$ and $300 \mathrm{mg}$ $\mathrm{L}^{-1}$ ), two strains of arbuscular mycorrhizal fungi (Acaulospora morrowiae and Gigaspora margarita) and a control treatment (without inoculation), with three replications. The arbuscular mycorrhizal fungi (AMFs) strains were provided by the International Glomeromycota Culture Collection (CICG) of the Regional 
University of Blumenau (FURB), Blumenau, Santa Catarina, Brazil. The inoculation was performed using a 3 $\mathrm{g}$ of inert vehicle (containing approximately 115 spores per tube).

The nutrient solution was renewed weekly and the inoculation was repeated. After 21 days of adaptation, the plants were submitted to treatment with increasing doses of lead, added in the form of lead nitrate $\left[\mathrm{Pb}\left(\mathrm{NO}_{3}\right)_{2}\right]$.

The nutrient solution was oxygenated by a system consisting of an air compressor (Resun GF180, 300 $\mathrm{L} \mathrm{min}^{-1}$ to $8 \mathrm{kPa}$ of pressure), connected to a PVC pipe forming a main air distribution line. The secondary lines were constituted by silicone hoses, $16 \mathrm{~mm}$ in diameter, coupled to a porous stone at its extremity. Daily the solution volume was checked and, if necessary, its initial level was restored with deionized water; $\mathrm{pH}$ of the solution was maintained in the range of 5.5 and 6.5 and the electric conductivity of the solution at 3.4 $\mathrm{mS} \mathrm{cm}{ }^{-1}$ measured with the portable conductivitymeter (Kasvi ${ }^{\circledR}$ ).

\section{Collection and analysis of the plants}

After 25 days of exposure to lead $\left(\mathrm{Pb}^{+2}\right)$, the plants were collected and separated into shoots and roots. The shoot was washed in deionized running water to remove particles that have adhered to the tissue and the roots were immersed for 5 minutes in a solution of $\mathrm{HCl} 0.1 \mathrm{~mol} \mathrm{~L}^{-1}$ to remove the metallic ions that have stuck to the surface and then washed with deionized water. The variables shoot length (SL), using a tape measure, diameter of the root collar (RC) obtained by digital pachymeter, number of leaves (NL) were measured using a graduated ruler. Then the plants were weighed to obtain the fresh mass of the shoot (FMS), fresh mass of root (FMR) and the volume of the roots measured using a graduated test tube.

The roots and shoot were placed in paper packages, submitted to drying in an oven with forced air circulation, at $65 \stackrel{\circ}{\circ}$, until the plant material reached a constant weight (about $72 \mathrm{~h}$ ) and the dry mass of the shoot (DMS) and of the roots (DMR) is obtained.

Once the dry masses had been looked at, the samples were ground in a Wiley type mill, digested in a nitro-perchloric acid solution, according to the methodology described by Tedesco et al. (1995) and the concentrations of the macronutrients phosphorus $(P)$, potassium $(K)$, sulphur $(S)$, calcium $(\mathrm{Ca})$ and magnesium (Mg) and of the metallic ion $(\mathrm{Pb})$ were determined. The vandato-yellow colorimetric method was used to determine P. It forms a complex in a yellow color that absorbs light in the $420 \mathrm{~nm}$ region. $\mathrm{K}$ was determined by flame photometer. $\mathrm{S}$ was determined by turbidimetry and the concentration values of $\mathrm{Ca}$, $\mathrm{Mg}$ and $\mathrm{Pb}$ were determined in an atomic absorption spectrometer (Varian ${ }^{\circledR} \mathrm{AA} 240 \mathrm{FS}$ ).

\section{Extraction and quantification of chlorophyll $a, b$ and totals and carotenoids}

The extraction of the photosynthetic pigments (chlorophyll $a, b$, totals and carotenoids) was performed using the methodology of Arnon (1949) and Hiscox and Tsraelstam (1979) with adaptations. Two hundred $\mathrm{mg}$ of plant material were weighed in a test tube wrapped in aluminum papers, adding to them 10 $\mathrm{mL}$ of dimethyl sulphoxide [ $\left.\left(\mathrm{CH}_{3}\right)_{2} \mathrm{SO}\right]$ and incubated at $70 \stackrel{\circ}{ } \mathrm{C}$ for $30 \mathrm{~min}$, in a water bath, followed by individual agitation, every $10 \mathrm{~min}$. The equipment used for reading pigments was the Biomate ${ }^{\circledR} \mathrm{tm} 3$ spectrophotometer, on the 470, 656 and $663 \mathrm{~nm}$ wavelengths, which were calibrated according to the transfer of an aliquot to a quartz cuvette with a $3 \mathrm{~cm}^{3}$ volume. Based on the absorbances obtained the respective values of carotenoids $(\mathrm{Cx}+\mathrm{c})$, chlorophyll $a$, chlorophyll $b$, and total chlorophyll were calculated, expressed in $\mu \mathrm{g} \mathrm{mL}^{-1}$ of extract, and were later converted into $\mu \mathrm{g} \mathrm{g}^{-1}$ of dry mass.

\section{Mycorrhizal colonization in the roots}

In order to evaluate the mycorrhizal colonization, about $1 \mathrm{~g}$ of the fine and fresh roots were collected, clarified and stained with trypan blue (Koske and Gemma 1989) and evaluated using the method of intersections in reticulated plates (Giovannetti and Mosse 1980) obtaining the mycorrhizal colonization rate. For the percentage of mycorrhizal colonization, the roots were spread on a Petri plate with a $1.1 \times 1.1 \mathrm{~cm}$ grid at the base, and both the horizontal and vertical lines of the grid were observed as well and the total number of intersections between roots and grid lines was written down, and also the number of intersections with mycorrhizal roots with some structure of the mycorrhizal fungi: vesicles, arbuscules, hyphae and spores. 


\section{Phytoextraction efficiency}

Based on the concentrations of the metals in the plant tissues and in the solutions, the following were determined: Total concentration of metals (TCM) obtained by the sum of the concentrations of metals in the root and in the shoot of plants, according to the equation: TCM $=[\text { Metal }]_{\text {root }}+[\text { Metal }]_{\text {shoot }}$. The efficiency of phytoextraction can be quantified calculating the bioconcentration factors (BCF), the translocation factor (TF) and the phytoextraction coefficient (PEC). The BCF indicates the biota efficiency to accumulate metal from the surrounding medium (solution) in its tissues (roots) (Mackay 1982), according to the equation $\mathrm{BCF}=[\text { Metal }]_{\text {root }} /[\text { Metal }]_{\text {solution. }}$. The TF indicate the plant capacity to translocate the metallic ion of the roots to the shoot (stem and leaves) according to the equation: TF $=[\mathrm{Metal}]_{\text {shoot }} /[\mathrm{Metal}]_{\text {root }}$ and PEC measures the plant efficiency in extracting the metal from the nutrient solution, according to equation: PEC $[\text { Metal }]_{\text {shoot + root }} /[\text { Metal }]_{\text {solution }}$.

\section{Statistical analysis}

The data obtained were submitted to analysis of variance applying the $F$ test (ANOVA), considering the significance at the traditional levels of 5 and $1 \%$ probability. Since a significant difference was found between the doses, they were submitted to regression analysis and between the fungal strains submitted to Tukey's test at $5 \%$ of probability. All analyses were performed in the Sisvar statistical program (Ferreira 2011).

\section{Results and Discussion}

In the response variables, dry mass of root (DMR), chlorophyll $a$, lead concentration in the shoot (sPb) and calcium in the root $(\mathrm{rCa}$ ) have a significant effect on interaction between increased lead concentrations and arbuscular mycorrhizal fungi (AMFs) inocula. To AMFs isolated has significant effect on root collar diameter (RC), fresh mass of root (FMR), mycorrhizal colonization (MC), phosphorus (sP) and potassium (sK) in the shoot and, magnesium in the root (rMg). A significant effect was observed in the increasing lead concentration in shoot length (SL), number of leaves (NL), leaf area (LA), fresh mass of shoot (FMS) and root (FMR), dry mass of shoot (DMS), root volume (RV), and lead concentration in the root ( $\mathrm{Pb})$. As observed by Alaboudi et al. (2018) when the concentration of heavy metals in the substrate increased, the fresh and dry weights of the growing plants gradually decreased.

The plant weights and lengths were smaller in all plants grown in a metal rich nutrient solution (300 $\left.\mathrm{mg} \mathrm{L}^{-1}\right)$ compared with the same plants grown in control and at low to moderate $\left(0\right.$ and $70 \mathrm{mg} \mathrm{L}^{-1}$, respectively) metal contaminated nutrient solution (Figure 1).

$V$. polyanthes plants exposed to increasing lead concentrations in the nutrient solution had a significant decrease of approximately $27.3,25.8,30.6,59.6,49.1,40.5,57.1$, and $29.1 \%$ in the morphological variables SL, SD, NL, LA, FMS, FMR, DMS and RV, respectively, with negative linear behavior (Figure $1 \mathrm{~A}$ to $1 \mathrm{H})$. However, in the variables related to the root system of $V$. polyanthes plants, fresh mass of root (FMR) and root volume (RV), the behavioral adjustment was a quadratic polynomial with reduction in concentrations above 250 and $270 \mathrm{mg} \mathrm{L}^{-1}$, respectively (Figures $1 \mathrm{~F}$ and $1 \mathrm{H}$ ). A possible response is an increase in the synthesis of polysaccharides of the cell wall and cell wall thickness (Rossato et al. 2012). Furthermore, according to Baligar et al. (1998), concentrations of lead below the toxic level stimulate the growth of the plant roots, which could explain the increase of the average values observed in the present study (Figures $1 \mathrm{~F}$ and $1 \mathrm{H})$. 
A
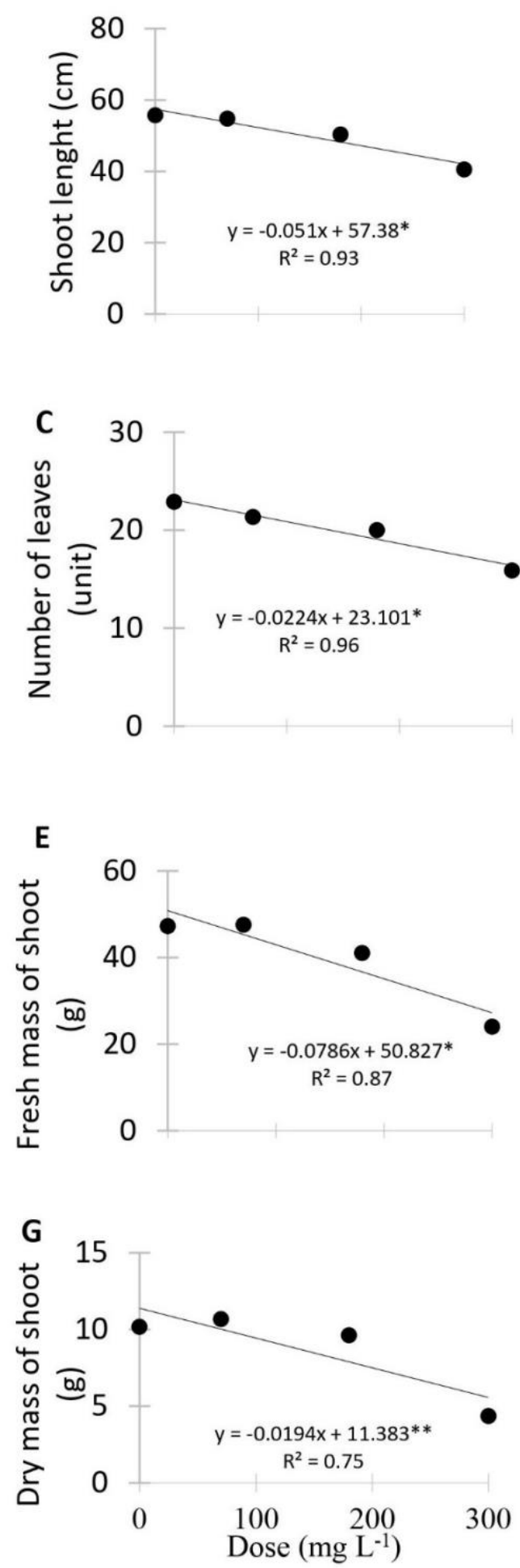
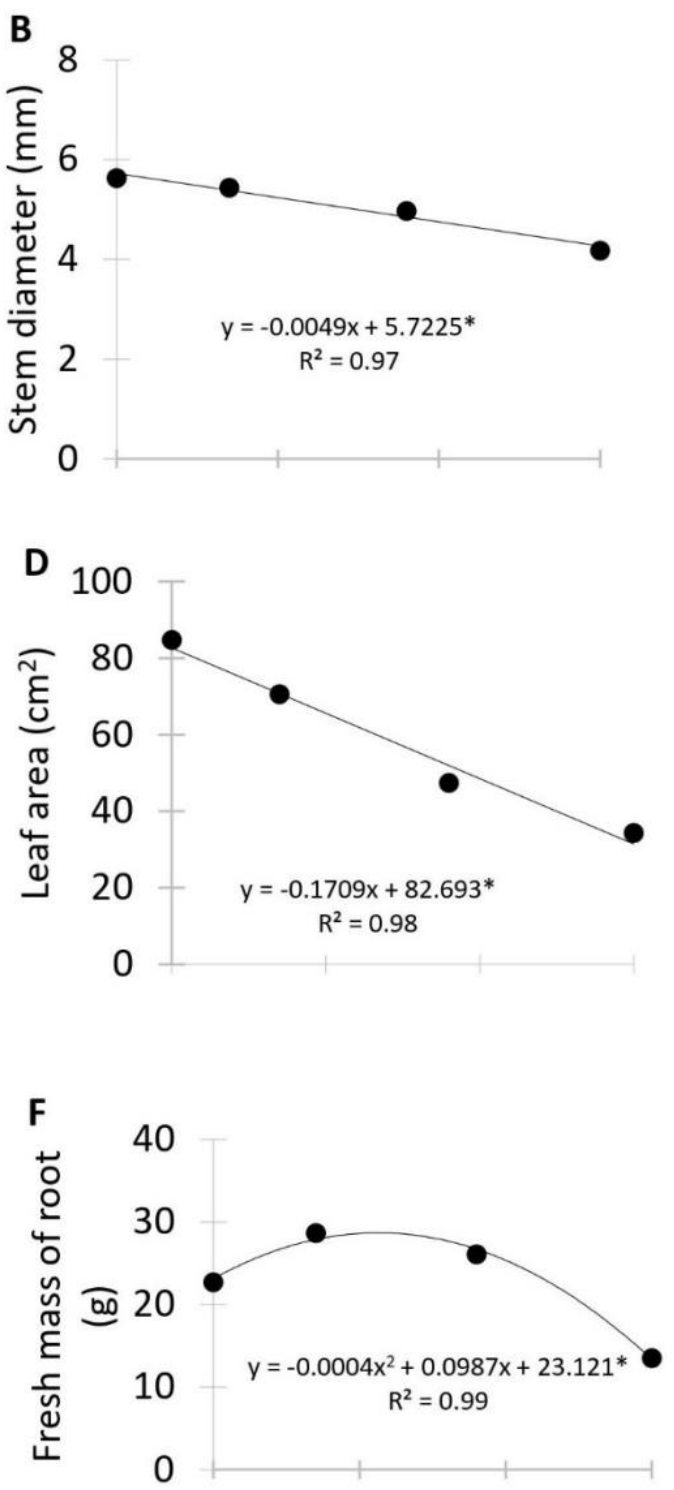

H

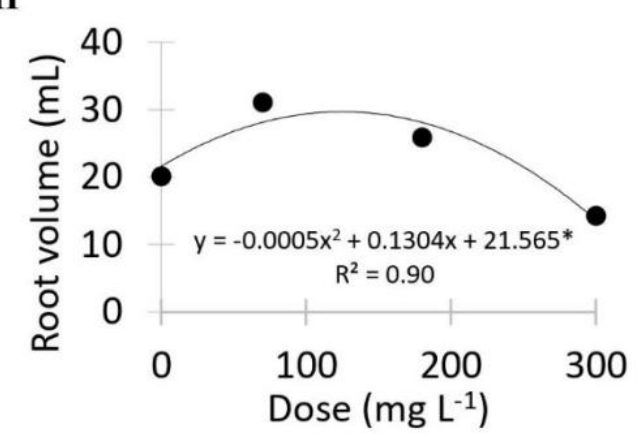

Figure 1. Morphological responses of Vernonia polyanthes plants grown in nutrient solution with increasing lead concentration. A - shoot length; B - stem diameter; C - number of leaves; D - leaf area;

$\mathrm{E}$ - fresh mass of shoot; $\mathrm{F}$ - fresh mass of root; $\mathrm{G}$ - dry mass of shoot; $\mathrm{H}$ - root volume.

* $\mathrm{e}^{* *}$ significant at 1 and $5 \%$, respectively.

In the study by Alves et al. (2008), vetiver [Vetiveria zizanioides (L.) Nash], jureminha [Desmanthus virgatus (L.) Willd] and algaroba [Prosopis juliflora (SW) DC] plants grown in a nutrient solution containing lead presented a reduction of DMS of 22.9, 32.7, and 24.3\%, respectively, at the dose of $200 \mathrm{mg} \mathrm{L}^{-1}$. Decreases in the leaf number and leaf area reflect $\mathrm{Pb}$ toxicity. Quebra-pedra (Phyllanthus niruri L.) plants also showed a reduction in leaf numbers when exposed to Pb concentrations $(100,200,400,800$ and 1600 $\mathrm{mg} \mathrm{kg}^{-1}$ of soil), showing sensitivity to $\mathrm{Pb}$ toxicity (Chandrasekhar and Ray 2019). The excessive amount of lead in soil may cause stress-induced changes in plants including growth reduction, decreased biomass, 
leaf chlorosis, many other physiological and biochemical changes (Yongsheng et al. 2011). In a study by Zhang et al. (2018), sunflower plants had organelles (thylakoids) damaged, inhibiting their growth in soil contaminated with multi-metals, including $\mathrm{Pb}$. Decline in growth and biomass are common indications of heavy metal-induced toxicity in plants (Rehman et al. 2017). The results of this study were similar to those reported by Chandrasekhar and Ray (2019), where plants of the species Eclipta prostrata L. known as quitoco, arnica, erva-botão, belonging to the same $V$. polyanthes family (Asteraceae) did not decrease the shoot length, fresh and dry weight and number of leaves, when grown in 100, 200, 400, 800 and $1600 \mathrm{mg}$ $\mathrm{kg}^{-1}$ of soil, and the authors considered the results an indication of the potential of that species to survive in soils contaminated with $\mathrm{Pb}$.

In the variable dry mass of root (DMR) there was a negative linear reduction with the increase of the lead concentration and inoculation with Gigaspora margarita fungus (GM). However, without inoculation and with the use of Acaulospora morrowiae fungus (AM), the adjustment was a quadratic polynomial negative with an increase in DMR and decrease from the approximate concentration of $125 \mathrm{mg} \mathrm{Pb} \mathrm{L}^{-1}$ (Figure $2 A)$. It's mean that the plants decreased the grown of the roots only after the toxic level, and below the toxic level the growth of the plant roots were stimulate (Baligar et al. 1998). Furthermore, phytotoxicity of $\mathrm{Pb}$ depends on the species, plant tissue, exposure period and concentration (Moraes et al. 2014).

Rossato et al. (2012) observed similar behavior in Pluchea sagittalis (Asteraceae) popularly known as quitoco or as arnica, where the plants decreased the grown of the roots only after the toxic level. The authors reported an increase of fresh and dry weight of the roots with the application of $200 \mu \mathrm{M} \mathrm{Pb} \mathrm{L}^{-1}$ of nutrient solution, decreasing the means with increasing of the Pb levels. Lead causes phytotoxicity by altering cell membrane permeability, reacting with active groups of different enzymes involved in plant metabolism, inhibition of ATP production, lipid peroxidation and DNA damage by excessive production of reactive oxygen species (ROS) (Kumar et al. 2017).
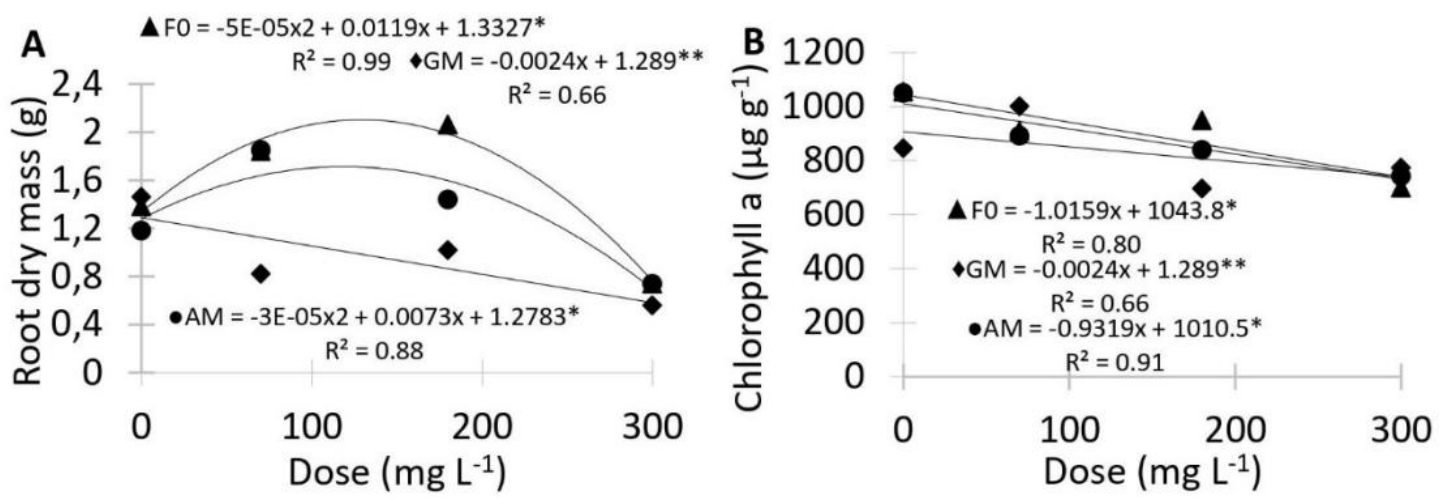

Figure 2. Dry mass of root and chorophyll a of Vernonia polyanthes plants grown in a nutrient solution

with increasing lead concentration and arbuscular mycorrhizal fungi inocula. A - root dry mass;

$\mathrm{B}$ - chlorophyll a. ${ }^{*}$ and ${ }^{* *}$ significant at 1 and $5 \%$, respectively. FO - treatment without fungi inoculation; GM - Gigaspora margarita; AM - Acaulospora morrowiae.

Figure 2B shows reduction in chlorophyll $a$ content of $29.19,33.71$ and $8.57 \%$ at the high concentration of lead ( $\left.300 \mathrm{mg} \mathrm{L}^{-1}\right)$ with $\mathrm{AM}, \mathrm{FO}$ and $\mathrm{GM}$, respectively, compared to the control $\left(0 \mathrm{mg} \mathrm{Pb} \mathrm{L}^{-1}\right)$. This result is explained because $\mathrm{Pb}$ considerably damages the antioxidant system, inducing oxidative stress due to the improved synthesis of reactive oxygen species (ROS) including superoxide anion $\left(\mathrm{O}_{2}{ }^{-}\right)$, singlet oxygen $\left({ }^{1} \mathrm{O}_{2}\right)$, hydrogen peroxide $\left(\mathrm{H}_{2} \mathrm{O}_{2}\right)$ and the hydroxyl radical $(\bullet \mathrm{OH})(\mathrm{Wu}$ et al. 2018). This process prevents the maintenance of chlorophyll $a$ and conversion to chlorophyll $b$ through an enzyme called chlorophyll $a$ oxygenase, which catalyzes the oxidation of the methyl group to the aldehyde group of these molecules (Xu et al. 2001). In addition, high concentrations of heavy metals damage the thylakoid in the chloroplast stroma negatively affecting photosynthesis (Yang et al. 2015).

Morphological variables have different responses to AM fungi (Table 1). Compared with the noninoculated control treatment, the stem diameter (SD) of the single inoculation of Acaulospora morrowiae (AM) decreased by $30 \%$, and the fresh mass of root (FMR) with Gigaspora margarita (GM) width by $30 \%$ 
(Table 1). Similar results were observed for dry mass of roots (Figure $2 \mathrm{~A}$ ). These results were probably related to the high concentrations of lead in nutrient solutions and to plant exposition.

Table 1. Stem diameter (SD), mycorrhizal colonization rate (MCR), fresh mass of root (FMR) and root $\mathrm{Mg}$ content $(\mathrm{rMg})$ of $V$. polyanthes plants exposed to lead in a nutrient solution.

\begin{tabular}{ccccc}
\hline Treatment & SD & MCR & RFM & rMg \\
\hline AM & $4.68^{\mathrm{b}}$ & $2.34^{\mathrm{a}}$ & $22.41^{\mathrm{ab}}$ & $2.82^{\mathrm{b}}$ \\
GM & $4.88^{\mathrm{ab}}$ & $3.32^{\mathrm{a}}$ & $18.90^{\mathrm{b}}$ & $2.98^{\mathrm{b}}$ \\
FO & $5.61^{\mathrm{a}}$ & $0.00^{\mathrm{b}}$ & $27.00^{\mathrm{a}}$ & $3.91^{\mathrm{a}}$ \\
\hline C.V. & 14.64 & 118.96 & 26.52 & 17.98 \\
\hline
\end{tabular}

*AM - Acaulospora morrowiae; GM - Gigaspora margarita; F0 - Treatment without fungi inoculation. Means followed the same letter do not differ by Tukey's test at $5 \%$.

No root infection was found in control plants (F0), and the mean proportion of root length colonized in inoculated plants ranging from 2.3 to 3.3\% (Table 1). Some publications reported the great efficacy of AM fungi and high sensitivity of isolates from unpolluted soils not adapted to the stress of contaminated soils (Hua et al. 2009). In addition, one of the effects of heavy metals on AMFs is the inhibition of spore germination and hyphae development, rendering mycorrhizae formation difficult, inhibition of colonization and decreased nutrition provided to the AMF (Chen et al. 2015; Yang et al. 2016).

The macronutrient concentrations $(P, K$ and $\mathrm{Mg})$ in the shoot and root of $V$. polyanthes decreased with increasing lead concentration in the nutrient solution (Tables 1 and 3; Figures $3 \mathrm{~A}, 3 \mathrm{~B}$, and $3 \mathrm{C}$ ). The $\mathrm{P}$ concentrations in the shoot of $V$. polyanthes decreased by $26.9,44.8$ and $38.1 \%$ according to increasing lead concentrations $\left(0,70,180\right.$ and $300 \mathrm{mg} \mathrm{L}^{-1}$, respectively) in the nutrient solution of (Figure $\left.3 \mathrm{~A}\right)$ ). A favorable $P$ regime in growth media is known to reduce the effects of $\mathrm{Pb}$ toxicity in plants since the ability of $\mathrm{Pb}$ to form insoluble phosphates in plant tissues is the answer to decreasing $\mathrm{P}$ absorption by plant root and translocation to the shoot (Kabata-Pendias 2011).
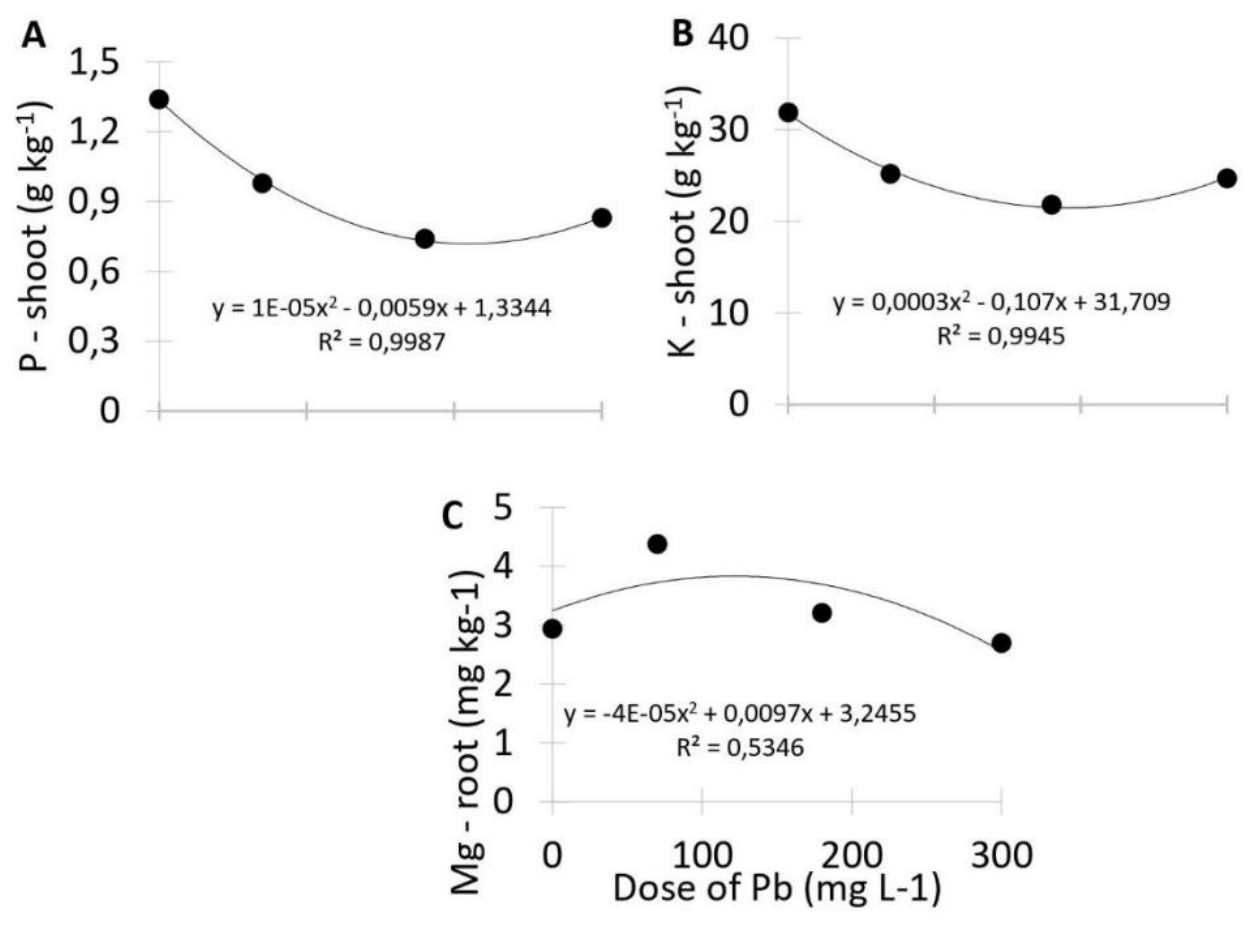

Figure 3. Macronutrient contents of $V$. polyanthes plants grown in nutrient solution with increasing lead concentration. $\mathrm{A}-\mathrm{P}$ in the shoot; $\mathrm{B}-\mathrm{K}$ in the shoot; $\mathrm{C}-\mathrm{Mg}$ in the root.

$* e^{* *}$ significant at a 1 e $5 \%$, respectively. 
No effect on phosphorus absorption was observed with inoculation of arbuscular mycorrhizal fungi. However, Meyer et al. (2017) observed increases in phosphorus concentration in the shoot and roots of vetiver grown on a heavy metal contaminated substrate.

The same results were observed for $\mathrm{K}$ concentration in the shoot of $V$. polyanthes (Figure 3B). According to Sharma and Dubey (2005), the strong interaction of $K$ ions with lead could result from their similar radii $(\mathrm{Pb}=1.29 \AA$ and $\mathrm{K}=1.33 \AA$ ). These two ions may compete for entry into the plant through the same potassium channels. Similarly, lead effects on K-ATPase and -SH groups of cell membrane proteins cause an efflux of $\mathrm{K}$ from the roots, which explains the decrease in $\mathrm{K}$ concentration with the increase of lead in the nutrient solution.

In Figure 3 it was observed that magnesium concentration (rMg) in the root of $V$. polyanthes decreases after exposure to $150 \mathrm{mg} \mathrm{L}^{-1}$ lead concentration and it is known that lead exposure decreases the concentration of divalent cations ( $\mathrm{Zn}, \mathrm{Mn}, \mathrm{Mg}, \mathrm{Ca}$, and $\mathrm{Fe}$ ) in leaves and roots (Zhang et al. 2018). Furthermore, $\mathrm{Pb}$ inhibits chlorophyll synthesis by causing impaired uptake of essential elements such as $\mathrm{Mg}$ and Fe by plants. It damages the photosynthetic apparatus due to its affinity for protein $\mathrm{N}$ - and S- ligands (Burzynski 1987; Ahmed and Tajmir-Riahi 1993; Sharma and Dubey 2005; Moraes et al. 2014).

The calcium concentration in the root of $V$. polyanthes decreased linearly with Gigaspora margarita (GM) inoculation. However, the opposite response was observed with Acaulospora morrowiae (AM) inoculation and in the non-inoculated plants these increases were observed after a dose of $180 \mathrm{mg} \mathrm{L}^{-1}$ (Figure 4).
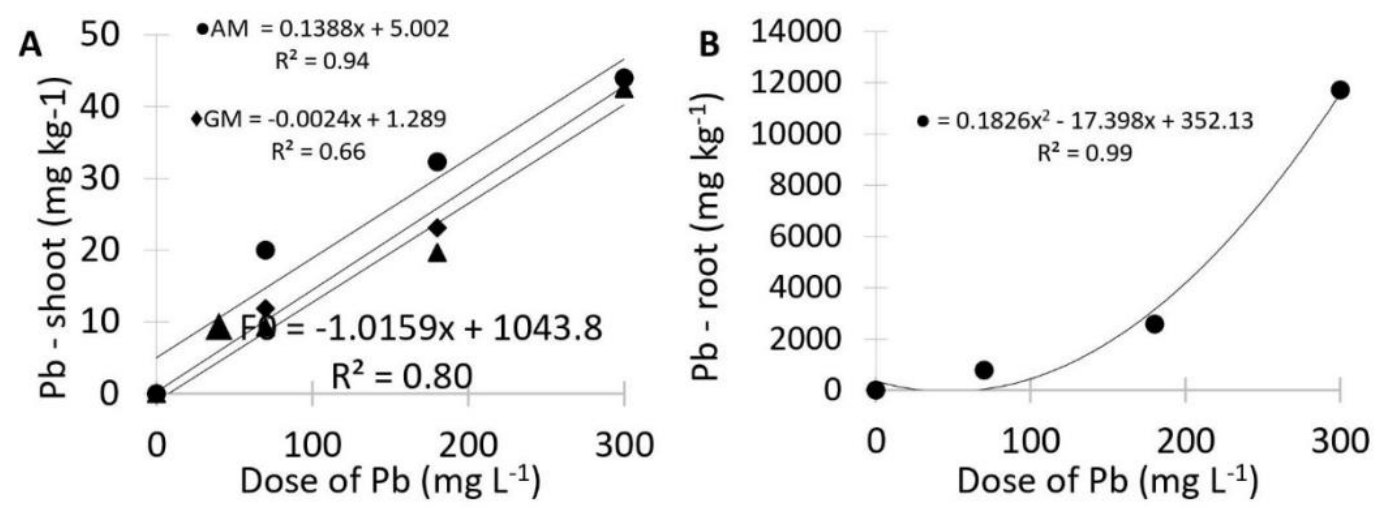

Figure 4. Lead contents in the shoot and root of $V$. polyanthes plants grown in nutrient solution with increasing lead concentration. $\mathrm{A}-\mathrm{Pb}$ in the shoot; $\mathrm{B}-\mathrm{Pb}$ in the root. ${ }^{*} \mathrm{e}^{* *}$ significant at a 1 and $5 \%$, respectively. FO - Treatment without fungi inoculation; GM - Gigaspora margarita;

AM - Acaulospora morrowiae.

In treatments $\mathrm{FO}$ and $\mathrm{AM}$ the concentrations of $\mathrm{Ca}$ in the root, in general, do not decrease or increase as observed in AM (Figure 4). This occurs, because the interference of $\mathrm{Pb}$ with $\mathrm{Ca}$ is metabolically important since $\mathrm{Pb}$ can mimic the physiological behavior of $\mathrm{Ca}$ and thus can inhibit some enzymes (Kabata-Pendias 2011). On the other hand, exposure to lead may decrease the concentration of divalent cations, including $\mathrm{Ca}^{2+}$ (Kumar et al. 2017). The reduction of $\mathrm{Ca}$ concentration with the increase of $\mathrm{Pb}$ concentration was observed in bean plants cultivated in a nutrient solution (Cannata et al. 2013). These results suggesting that the enhancements of $\mathrm{P}, \mathrm{K}, \mathrm{Mg}$, and $\mathrm{Ca}$ in mycorrhizal and non- mycorrhizal plants grown on substrate containing metals probably depend on plant species, AMF species and soil conditions (Clark and Zeto 2000).

The doses of 70,180, and $300 \mathrm{mg} \mathrm{L}^{-1}$ presented the lowest averages for $\mathrm{Pb}$ concentration in the shoot of plants without the application of AMF $\left(9.2 ; 19.7 ; 42.5 \mathrm{mg} \mathrm{kg}^{-1}\right.$ dry mass, respectively). The highest averages (20.0, 32.3 and $44.0 \mathrm{mg} \mathrm{kg}^{-1}$ ) were observed with the application of the AM fungus at all doses applied in the present study (Figure $4 \mathrm{~A}$ ). Probably, $\mathrm{Pb}$ may have increased in the shoots of inoculated plants due to the reduction of biomass as a consequence of the higher metal absorption (Figures 1 and 2; Table 1).

Regarding $\mathrm{Pb}$ concentration in the roots of $V$. polyanthes plants, there was no significant effect for factor interaction ( $\mathrm{Pb}$ dose and fungus) and for the fungus factor. However, the dose factor had a significant effect (Table 1; Figure 4B). Zhang et al. (2018) observed that inoculation of AMF (Funneliformis mosseae and 
Funneliformis caledonium) did not significantly affect the concentration of $\mathrm{Cd}, \mathrm{Cu}, \mathrm{Pb}, \mathrm{Cr}, \mathrm{Zn}$ and $\mathrm{Ni}$ in

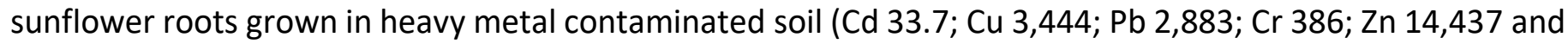
$\mathrm{Ni} 373 \mathrm{mg} \mathrm{kg}{ }^{-1}$ ), also no differences were found in shoot $\mathrm{Pb}$ concentrations of legumes (Robinia pseudoacacia, Trifolium pretense and Medicago sativa) and grass (Lolium perenne) between non-mycorrhizal and mycorrhizal plants at $500 \mathrm{mg} \mathrm{kg}^{-1} \mathrm{~Pb}$ stress level (Yang et al. 2016).

Gigaspora margarita fungi positively aided the growth of vetiver (Chrysopogon zizanioides) even with a low colonization rate (6.4\%) (Meyer et al. 2017). As previously mentioned, AMF inoculation resulted in higher $\mathrm{Pb}$ translocation, resulting in a smaller diameter in V. polyanthes plants (Table 2). Mnasri et al. (2017), when evaluating the effect of AMFs on heavy metal absorption, in Medicago sativa L. observed that AMFs increased the concentration of heavy metals in both roots and shoots. According to Ferrol et al. (2016) AMFs increase the transfer of essential micronutrients, but also nonessential elements to plant tissues.

The lead content in dry mass of root ranged from $780.0\left(70 \mathrm{mg} \mathrm{L}^{-1}\right)$ to $11,724.4 \mathrm{mg} \mathrm{kg}^{-1} \mathrm{~Pb}\left(300 \mathrm{mg} \mathrm{L}^{-}\right.$ $\left.{ }^{1}\right)$. Exposure of the $V$. polyanthes plant at 180 and $300 \mathrm{mg} \mathrm{L}^{-1}$ increased 230 and $1403 \%$ of the root metal content compared to $70 \mathrm{mg} \mathrm{L}^{-1}$ (Figure 4B). The increase in $\mathrm{Pb}$ accumulation in plant roots due to the application of increasing doses of $\mathrm{Pb}$ was reported by Roongtanakiat and Sanoh (2011) and Alves et al. (2016). The latter authors found in the roots a maximum Pb content of $24,762 \mathrm{mg} \mathrm{kg}^{-1}$ (dose of $303 \mathrm{mg} \mathrm{L}^{-1}$ $\mathrm{Pb}$ ) in vetiver; $12,897 \mathrm{mg} \mathrm{kg}^{-1}$ (dose of $400 \mathrm{mg} \mathrm{L}^{-1}$ ) in castor bean; 9,517 $\mathrm{mg} \mathrm{kg}^{-1}$ (dose of $400 \mathrm{mg} \mathrm{L}^{-1}$ ) in sunflower. $\mathrm{Pb}$ accumulation was greater in roots than that in shoots of all plants. Lead accumulates mainly in root cells due to blockage by caspary striae within the endoderm, sequestration in rhizodermal and cortical cell vacuoles, immobilization by negatively charged pectins within the cell wall, and accumulation in plasma membranes (Kopittke et al. 2007; Jiang and Liu 2010).

Phytoextraction coefficient (FC), bioaccumulation factor (BF), Translocation factor (TF) and, total concentration of metals (TCM) values ranged from 0.0 to $41.4 ; 0.0$ to $41.39 ; 0.0$ to 0.03 and; 0.0 to $12,460.67$, respectively (Table 2). Plants can be classified as accumulators, excluders and indicators according to the bioaccumulation factor, taking into consideration the capacity to accumulate heavy metals (Ma et al. 2001). Phytoremediation efficiency is evaluated by bioaccumulation factors of metals in different plant tissues and is used in several phytoremediation studies in hydroponic systems such as Batista et al. (2017) in the phytoremediation of $\mathrm{Pb}$ or in the environmental impact assessment in areas contaminated by multiple metals, as in the research conducted by Boechat et al. (2016a; 2016b).

In general, for all factors increasing lead concentration increased values, except to TF (Table 2). BCF and TF can be used as indicators of the phytoremediation potential exhibited by plant species. For a plant to be considered efficient in translocating metal from roots to the shoot, TF must be equal to/or greater than 1. Plants with BCF greater than 1 and translocation factor less than 1 (BCF $>1$ and FT < 1) have a potential for phytostabilization. Phytostabilization is a technology that involves altering soil and metal-tolerant plants to establish ground cover by reducing metal migration to air, surface and groundwater and reducing soil toxicity (Kodre et al. 2017). 
Table 2. Bioaccumulation factors in V. polyanthes plants cultivated in a hydroponic system with increasing lead concentration.

\begin{tabular}{ccccc}
\hline Treatment & PEC & \multicolumn{4}{l}{ BCF } & TF & TCM \\
\hline & \multicolumn{4}{c}{ Treatment without fungi } \\
\cline { 2 - 4 } 70 & 0.00 & 0.00 & 0.000 & 0.00 \\
180 & 6.15 & 6.02 & 0.012 & 430.45 \\
300 & 14.63 & 14.52 & 0.005 & 2633.70 \\
& 37.69 & 37.55 & 0.004 & 11306.85 \\
\cline { 2 - 4 } 0 & 0.00 & 0.00 & 0.00 \\
70 & 18.02 & 17.85 & 0.000 & 1261.23 \\
180 & 15.71 & 15.58 & 0.022 & 2828.13 \\
300 & 38.45 & 38.31 & 0.008 & 11536.42 \\
& \multicolumn{4}{c}{ Acaulospora morrowiae } \\
0 & 0.00 & 0.00 & 0.004 & 0.00 \\
70 & 9.87 & 9.58 & 0.000 & 690.68 \\
180 & 13.00 & 12.82 & 0.014 & 2339.67 \\
300 & 41.54 & 41.39 & 0.004 & 12460.67 \\
\hline
\end{tabular}

PEC - phytoextraction coefficient; BCF - bioconcentration factor; TF - translocation factor; TCM - total concentration of metals.

TF values ranged from 0.004 to 0.03 (Table 2). These results indicate that the $V$. polyanthes plant was not efficient in translocating large amounts of $\mathrm{Pb}$ from roots to shoots and was not considered a plant suitable for phytoextraction in contaminated areas. In these cases, the biomass production of the shoot of the plants and the amount of metal removed should be considered, as in these cases it would be justified to use it due to growth tolerance in extremely contaminated environments. Therefore, the $V$. polyanthes plant is a strong candidate for phytostabilization programs considering that it has such characteristics, since the lowest dose (70 $\mathrm{mg} \mathrm{L}^{-1}$ ) studied. According to Garg and Chandel (2010) in some cases, mycorrhizal plants show the characteristic of phytostabilization, reducing the translocation of heavy metals to the shoot. However, in the present study, arbuscular mycorrhizal fungi increased $\mathrm{Pb}$ translocation from roots to shoots (Figure 4A).

Correlation analyses were performed between the concentration of $\mathrm{Pb}$ and macronutrients in the shoots of the $\mathrm{V}$. polyanthes plant grown at increasing doses of $\mathrm{Pb}$. Significant negative correlations were found between $\mathrm{Pb}$ levels with $\mathrm{Ca}$ and $\mathrm{P}$ (Table 3). 
Table 3. Pearson correlation coefficients between lead concentration and macronutrient concentration in the shoot and root of $V$. polyanthes plants.

\begin{tabular}{|c|c|c|c|c|c|}
\hline Ion & $\mathrm{Ca}^{2+}$ & $\mathrm{Mg}^{2+}$ & $\mathrm{PO}_{4}{ }^{3-}$ & $\mathrm{K}^{+}$ & $\mathrm{SO}_{4}^{2-}$ \\
\hline & \multicolumn{4}{|c|}{ Shoot } & \\
\hline $\mathrm{Pb}^{2+}$ & $-0.593^{*}$ & $0.242^{\text {ns }}$ & $-0.738^{* *}$ & $-0.553^{\mathrm{ns}}$ & $-0.333^{n s}$ \\
\hline $\mathrm{Ca}^{2+}$ & 1 & $0.166^{\mathrm{ns}}$ & $0.626^{*}$ & $0.455^{\mathrm{ns}}$ & $0.601^{*}$ \\
\hline $\mathrm{Mg}^{2+}$ & na & 1 & $-0.115^{\mathrm{ns}}$ & $-0.0179^{n s}$ & $0.439^{\text {ns }}$ \\
\hline $\mathrm{PO}_{4}{ }^{3-}$ & na & na & 1 & $0.795^{* *}$ & $0.603^{*}$ \\
\hline $\mathrm{K}^{+}$ & na & na & na & 1 & $0.364^{\mathrm{ns}}$ \\
\hline $\mathrm{SO}_{4}{ }^{2-}$ & na & na & na & na & 1 \\
\hline \multirow[t]{2}{*}{ Ion } & $\mathrm{Ca}^{2+}$ & $\mathrm{Mg}^{2+}$ & $P$ & $\mathrm{~K}^{+}$ & $S$ \\
\hline & \multicolumn{4}{|c|}{ Root } & \\
\hline $\mathrm{Pb}^{2+}$ & $0.127^{\mathrm{ns}}$ & $-0.525^{\mathrm{ns}}$ & $0.210^{\text {ns }}$ & $-0.625^{*}$ & $0.206^{\mathrm{ns}}$ \\
\hline $\mathrm{Ca}^{2+}$ & 1 & $0.166^{\mathrm{ns}}$ & $0.868^{* *}$ & $0.532^{\mathrm{ns}}$ & $0.749^{* *}$ \\
\hline $\mathrm{Mg}^{2+}$ & na & 1 & $-0.0104^{\mathrm{ns}}$ & $0.484^{\mathrm{ns}}$ & $0.211^{\mathrm{ns}}$ \\
\hline $\mathrm{PO}_{4}^{3-}$ & na & na & 1 & $0.417^{\mathrm{ns}}$ & $0.551^{\mathrm{ns}}$ \\
\hline $\mathrm{K}^{+}$ & na & na & na & 1 & $0.481^{\mathrm{ns}}$ \\
\hline $\mathrm{SO}_{4}{ }^{2-}$ & na & na & na & na & 1 \\
\hline
\end{tabular}

** significant at $1 \%$; $*$ significant at $5 \%$; ns - not significant at 5\%; na - not apply.

The decrease of $\mathrm{P}$ with increasing $\mathrm{Pb}$ concentration was also evidenced in Figure $3 \mathrm{~A}$ and explained by antagonism between these elements. According to Kabata-Pendias (2011) P absorption is reduced with the increase of $\mathrm{Pb}$ concentration. To $\mathrm{Ca}^{2+}$, its reduction with the increase of $\mathrm{Pb}$ concentration can be explained by the competition between them. Marschner (1995) states that divalent cations such as $\mathrm{Pb}^{2+}$ compete with other cations such as $\mathrm{Ca}^{2+}$. Regarding the roots of cultivated $V$. polyanthes plants in increasing doses of $\mathrm{Pb} 2+$, it was noted that there were significant negative correlations for $\mathrm{Pb}^{2+}$ and $\mathrm{K}^{+}$contents only (Table 3 ). Increased $\mathrm{Pb}^{2+}$ absorption decreae $\mathrm{K}+$ absorption. High $\mathrm{Pb}$ concentrations decrease $\mathrm{K}^{+}$absorption, similarly to $\mathrm{Mg}^{2+}$ and $\mathrm{Ca}^{2+}$ which at high concentrations decrease $\mathrm{K}^{+}$absorption by plant roots (Cannata et al. 2013).

\section{Conclusions}

The present study indicates that the Vernonia polyanthes plant is tolerant to high concentrations of lead and capable of accumulating significant amounts of $\mathrm{Pb}$ in the roots. It is classified as a bioaccumulator of $\mathrm{Pb}$ in the root system and can be used in phytostabilization projects. Mycorrhizal fungi increase the accumulation of $\mathrm{Pb}$ in the shoot and can be used in projects aimed at heavy metal phytoextraction. Lead at high concentrations decreases the quality of morpho-physiological variables and the absorption of magnesium, phosphorus and potassium in $V$. polyanthes plants. The results suggest that the increase of the major elements in mycorrhizal and non-mycorrhizal plants grown on substrate containing lead nitrate depend on the plant species, AMF species and conditions of the culture medium.

Authors' Contributions: MORAIS, J.: conception and design, acquisition of data, analysis and interpretation of data, drafting the article, and critical review of important intellectual content; BOECHAT, C.L.: conception and design, acquisition of data, analysis and interpretation of data, drafting the article, and critical review of important intellectual content; OLIVEIRA, D.F.: conception and design, acquisition of data, analysis and interpretation of data, drafting the article, and critical review of important intellectual content; ARAUCO, A.M.S.: conception and design, acquisition of data, analysis and interpretation of data, drafting the article, and critical review of important intellectual content; CARLOS, F.S.: conception and design, acquisition of data, analysis and interpretation of data, drafting the article, and critical review of important intellectual content; SOARES, P.P.S.: conception and design, acquisition of data, analysis and interpretation of data, drafting the article, and critical review of important intellectual content. All authors have read and approved the final version of the manuscript.

Conflicts of Interest: The authors declare no conflicts of interest.

Ethics Approval: Not applicable. 
Acknowledgments: The authors would like to thank the funding for the realization of this study provided by the Brazilian agencies FAPEMA (Fundação de Amparo à Pesquisa e ao Desenvolvimento Científico e Tecnológico do Maranhão - Brasil), and CNPq (Conselho Nacional de Desenvolvimento Científico e Tecnológico - Brasil).

\section{References}

AHMED, A. and TAJMIR-RIAHI, H.A. Interaction of toxic metal ions $\mathrm{Cd}^{2+}, \mathrm{Hg}^{2+}$ and $\mathrm{Pb}$ with light-harvesting proteins of chloroplast thylakoid membranes. An FTIR spectroscopic study. Journal Inorganic Biochemistry. 1993, 50, 235-243. https://doi.org/10.1016/0162-0134(93)80050-J

ALABOUDI, K.A., et al. Phytoremediation of $\mathrm{Pb}$ and $\mathrm{Cd}$ contaminated soils by using sunflower (Helianthus annuus) plant. Annals of Agricultural Sciences. 2018, 63(1), 123-127. https://doi.org/10.1016/j.aoas.2018.05.007

ALVES, J.C., et al. Absorção e distribuição de chumbo em plantas de vetiver, jureminha e algaroba. Revista Brasileira de Ciência do Solo. 2008, 32(3), 1329-1336. https://doi.org/10.1590/S0100-06832008000300040

ALVES, J.C., et al. Potential of sunflower, castor bean, common buckwheat and vetiver as lead phytoaccumulators. Revista Brasileira de Engenharia Agrícola e Ambiental. 2016, 20(3), 243-249. https://doi.org/10.1590/1807-1929/agriambi.v20n3p243-249

ARIAS, M.S.B., et al. Enhanced Pb absorption by Hordeum vulgare L. and Helianthus annuus L. plants inoculated with an arbuscular mycorrhizal fungi consortium. International Journal of Phytoremediation. 2015, 17(5), 405-413. https://doi.org/10.1080/15226514.2014.898023

ARNON, D.I. Copper enzymes in isolated chloroplasts: polyphenoloxydase in Beta vulgaris. Plant Physiology. 1949, 24(1), 1-15.

https://doi.org/10.1104/pp.24.1.1

BALIGAR, V.C., et al. Toxicology and nutrient constraints on root growth. Hortscience. 1998, 33(6), 960-965.

https://doi.org/10.21273/HORTSCl.33.6.960

BATISTA, A.A., et al. Induced changes in the growth of four plant species due to lead toxicity. Revista Brasileira de Engenharia Agrícola e Ambiental. 2017, 21(5), 327-332. https://doi.org/10.1590/1807-1929/agriambi.v21n5p327-332

BOECHAT, C.L., et al. Heavy metals and nutrients uptake by medicinal plants cultivated on multi-metal contaminated soil samples from an abandoned gold ore-processing site. Water, Air and Soil Pollution. 2016a, 24, 3063-3073. https://doi.org/10.1007/s11270-016-3096-4

BOECHAT, C.L., et al. Accumulation and translocation of heavy metal by spontaneous plants growing on multi-metal-contaminated site in the Southeast of Rio Grande do Sul state, Brazil. Environmental Science and Pollution Research. 2016b, 23(3), 2371-2380.

https://doi.org/10.1007/s11356-015-5342-5

BURZYNSKI, M. The influence of lead and cadmium on the absorption and distribution of potassium, calcium, magnesium and iron in cucumber seedlings. Acta Physiologiae Plantarum. 1987, 9, 229-238.

CANNATA, M.G., et al. Effects of lead on the content, accumulation, and translocation of nutrients in bean plant cultivated in nutritive solution. Communications in Soil Science and Plant Analysis. 2013, 44(5), 939-951. https://doi.org/10.1080/00103624.2012.747605

CHANDRASEKHAR, C. and RAY, J.G. Lead accumulation, growth responses and biochemical changes of three plant species exposed to soil amended with different concentrations of lead nitrate. Ecotoxicology and Environmental Safety. 2019, 171, 26-36.

https://doi.org/10.1016/j.ecoenv.2018.12.058

CHEN, L., et al. The effects of arbuscular mycorrhizal fungi on sex-specific responses to Pb pollution in Populus cathayana. Ecotoxicology Environmental Safety. 2015, 113, 460-468. https://doi.org/10.1016/j.ecoenv.2014.12.033

CLARK, R.B. and ZETO, S.K. Mineral acquisition by arbuscular mycorrhizal plants. Journal of Plant Nutrition. 2000, 23, 867-902 https://doi.org/10.1080/01904160009382068

CONINX, L., et al., 2017. Mycorrhiza-assisted phytoremediation. In: A. Cuypers, J. Vangronsveld (Eds.), Advances in Botanical Research, v. 83, London: Academic Press, p.127-188. https://doi.org/10.1016/bs.abr.2016.12.005

FERREIRA, D.F. Sisvar: a computer statistical analysis system. Ciência e Agrotecnologia. 2011, 35, 1039-1042. https://doi.org/10.1590/S141370542011000600001

FERROL, N., et al. The heavy metal paradox in arbuscular mycorrhizas: from mechanisms to biotechnological applications. Journal of Experimental Botany. 2016, 67(22), 6253-6265. https://doi.org/10.1093/jxb/erw403

GARG, N. and CHANDEL, S. Arbuscular Mycorrhizal Networks: Process and Functions. Agronomy for Sustainable Development. 2010, 30, 581599. https://doi.org/10.1051/agro/2009054

GIOVANNETTI, M. and MOSSE, B. Anevaluation of techniques formeasuring vesicular arbuscular mycorrhizal infection in roots. New Phytologist. 1980, 84(3), 489-500. https://doi.org/10.1111/j.1469-8137.1980.tb04556.x

HISCOX, J.D. and ISRAELSTAM, G.F. A method for the extraction of chlorophyll from leaf tissue without maceration. Canadian Journal of Botany. 1979, 57(12),1332-1334. https://doi.org/10.1139/b79-163

HOAGLAND, D.R. and ARNON, D.I. The Water-cultured method for growing plants without soil. California Agricultural Experiment Station Circular. 1950, 347, 1-32. 
HUA, J., et al. Effects of arbuscular mycorrhizal fungi inoculation on arsenic accumulation by tobacco (Nicotiana tabacum L.). Journal of Environmental Sciences. 2009, 21(9), 1214-1220. https://doi.org/10.1016/S1001-0742(08)62406-7

INMET - Instituto Nacional de Meteorologia. Banco de Dados Meteorológicos para Ensino e Pesquisa. 2018. Access in march 20 2019. Available from http//www.inmet.gov.br/projetos/rede/pesquisa

JIANG, W. and LIU, D. Pb-induced cellular defense system in the root meristematic cells of Allium sativum L. BMC Plant Biology. $2010,10,40$. https://doi.org/10.1186/1471-2229-10-40

KABATA-PENDIAS, A. Trace elements in soils and plants. 4.ed. Boca Raton: CRC Press/Taylor \& Francis Group, 2011. https://doi.org/10.1201/b10158

KODRE, A., et al. Arbuscular mycorrhizal fungi alter $\mathrm{Hg}$ root uptake and ligand environment as studied by $\mathrm{X}$-ray absorption fine structure. Environmental and Experimental Botany. 2017, 133, 12-23. https://doi.org/10.1016/j.envexpbot.2016.09.006

KOPITTKE, P.M., et al. Toxic effects of $\mathrm{Pb}^{2+}$ on growth of cowpea (Vigna unguiculata). Environment Pollution. 2007, 150(2), $280-287$. https://doi.org/10.1016/j.envpol.2007.01.011

KOSKE, R.E. and GEMMA, J.N. A modified procedure for to detect VA mycorrhizas. Mycological Research. 1989, 92(4), $486-488$. https://doi.org/10.1016/S0953-7562(89)80195-9

KUMAR, B., et al. Plant mediated detoxification of mercury and lead. Arabian Journal of Chemistry. 2017, 10(2), $2335-2342$. https://doi.org/10.1016/j.arabjc.2013.08.010

LAJAYER, B.A., et al. Heavy metals in contaminated environment: Destiny of secondary metabolite biosynthesis, oxidative status and phytoextraction in medicinal plants. Ecotoxicology and Environmental Safety. 2017, 145, 377-390.

https://doi.org/10.1016/j.ecoenv.2017.07.035

MA, L.Q., et al. A fern that hyperaccumulates arsenic. Nature. 2001, 409, 579. https://doi.org/10.1038/35054664

MA, Y., et al. Potential of plant beneficial bacteria and arbuscular mycorrhizal fungi in phytoremediation of metal-contaminated saline soils. Journal of Hazardous Materials. 2019, 379(5), 120813. https://doi.org/10.1016/j.jhazmat.2019.120813

MACKAY, D. Correlation of bioconcentration factors. Environmental Science \& Technology. 1982, 16(5), 274-278.

https://doi.org/10.1021/es00099a008

MARSCHNER, H. Mineral nutrition of higher plants. 2nd ed. London: Academic Press, 1995. https://doi.org/10.1016/C2009-0-02402-7

MEYER, E., et al. Arbuscular mycorrhizal fungi in the growth and extraction of trace elements by Chrysopogon zizanioides (vetiver) in a substrate containing coal mine wastes. International Journal of Phytoremediation. 2017, 19(2), 113-120.

https://doi.org/10.1080/15226514.2016.1207596

MNASRI, M., et al. Comparison of arbuscular mycorrhizal fungal effects on the heavy metal uptake of a host and a non-host plant species in contact with extraradical mycelial network. Chemosphere. 2017, 171, 476-484. https://doi.org/10.1016/j.chemosphere.2016.12.093

MORAES, C.L., et al. Alterações fisiológicas e ultraestruturais de plântulas de tomate induzidas por chumbo. Iheringia Série Botânica. 2014, 69(2), 313-322.

PEREIRA, K.L., et al. Potencial fitorremediador das plantas predominantes na área do lixão de Inconfidentes/MG. Revista Agrogeoambiental. 2013, 1, 25-29. http://dx.doi.org/10.18406/2316-1817v1n12013566

REHMAN, M.Z.U., et al. Remediation of heavy metal contaminated soils by using Solanum nigrum: a review. Ecotoxicology and Environmental Safety. 2017, 143, 236-248. https://doi.org/10.1016/j.ecoenv.2017.05.038

ROONGTANAKIAT, N. and SANOH, S. Phytoextraction of zinc, cadmium and lead from contaminated soil by vetiver grass. Kasetsart Journal, Natural Science. 2011, 45(4), 603-612.

ROSSATO, L.V., et al. Effects of lead on the growth, lead accumulation and physiological responses of Pluchea sagittalis. Ecotoxicology. 2012, 21(1), 111-123. https://doi.org/10.1007/s10646-011-0771-5

SHARMA, P. and DUBEY, R.S. Lead toxicity in plants. Brazilian Journal of Plant Physiology. 2005, 17(1), 35-52. https://doi.org/10.1590/S1677$\underline{04202005000100004}$

SMITH, S.E. and SMITH, F.A. Fresh perspectives on the roles of arbuscular mycorrhizal fungi in plant nutrition and growth. Mycologia. 2012, 104(1), 1-13. https://doi.org/10.3852/11-229

TEDESCO, M.J., et al. Análise de solo, plantas e outros materiais. 2.ed. Porto Alegre: UFRGS, 1995.

VERGARA, C., et al. Plant-mycorrhizal fungi interaction and response to inoculation with different growth-promoting fungi. Pesquisa Agropecuária Brasileira. 2019, 54, e25140. https://doi.org/10.1590/S1678-3921.pab2019.v54.25140

$\mathrm{XU}, \mathrm{H}$., et al. Chlorophyll b can serve as the major pigment in functional photosystem II complexes of cyanobacteria. Proceedings of the National Academy of Science. 2001, 98(24), 4168-14173. https://doi.org/10.1073/pnas.251530298

YANG, Y., et al. The roles of arbuscular mycorrhizal fungi (AMF) in phytoremediation and tree-herb interactions in Pb contaminated soil. Scientific Reports. 2016, 6, 20469. https://doi.org/10.1038/srep20469 
YANG, Y., et al. The combined effects of arbuscular mycorrhizal fungi (AMF) and lead (Pb) stress on pb accumulation, plant growth parameters, photosynthesis, and antioxidant enzymes in Robinia pseudoacacia L. PLoS One. 2015, 10(12), e0145726, 1-24.

https://doi.org/10.1371/journal.pone.0145726

YONGPISANPHOP, J., et al. Phytoremediation Potential of Plants Growing on the Pb-Contaminated Soil at the Song Tho Pb Mine, Thailand. Soil and Sediment Contamination. 2017, 26, 426-437. https://doi.org/10.1080/15320383.2017.1348336

YONGSHENG, W., et al. Effect of $\mathrm{Pb}$ on the growth, accumulation and quality component of the tea plant. Procedia Engineering. 2011, 18, 214219. https://doi.org/10.1016/j.proeng.2011.11.034

WU, W., et al. Assessment of heavy metal pollution and human health risks in urban soils around an electronics manufacturing facility. Science of the Total Environment. 2018, 630, 53-61. https://doi.org/10.1016/j.scitotenv.2018.02.183

ZHANG, Y., et al.Arbuscular mycorrhizal fungi alleviate the heavy metal toxicity on sunflower (Helianthus annuus L.) plants cultivated on a heavily contaminated field soil at a WEEE-recycling site. Science of The Total Environment. 2018, 628, 282-290.

https://doi.org/10.1016/j.scitotenv.2018.01.331

Received: 9 April 2020 | Accepted: 14 December 2020 | Published: 20 August 2021

This is an Open Access article distributed under the terms of the Creative Commons Attribution License, which permits unrestricted use, distribution, and reproduction in any medium, provided the original work is properly cited. 